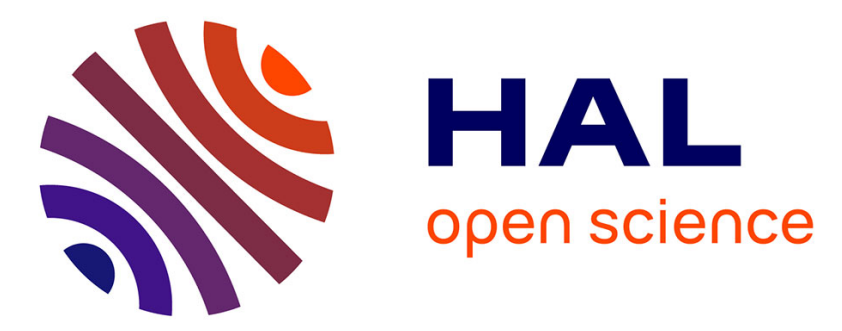

\title{
Quantitative proteomic analysis of bacterial enzymes released in cheese during ripening
}

Valérie Gagnaire, Julien Jardin, Daniel Mollé, Michel Piot, Sylvie Lortal

\section{To cite this version:}

Valérie Gagnaire, Julien Jardin, Daniel Mollé, Michel Piot, Sylvie Lortal. Quantitative proteomic analysis of bacterial enzymes released in cheese during ripening. 5 th international IDF symposium on cheese ripening, Mar 2008, Bern, Switzerland. Dairy Science and Technology, 88 (4/5), 605 p., 2008, Dairy Science and Technology. hal-01454387

\section{HAL Id: hal-01454387 https://hal.science/hal-01454387}

Submitted on 3 Jun 2020

HAL is a multi-disciplinary open access archive for the deposit and dissemination of scientific research documents, whether they are published or not. The documents may come from teaching and research institutions in France or abroad, or from public or private research centers.
L'archive ouverte pluridisciplinaire HAL, est destinée au dépôt et à la diffusion de documents scientifiques de niveau recherche, publiés ou non, émanant des établissements d'enseignement et de recherche français ou étrangers, des laboratoires publics ou privés.

$$
\text { Copyright }
$$




\title{
Quantitative proteomic analysis of bacterial enzymes released in cheese during ripening
}

\author{
Julien Jardin, Daniel Mollé, Michel Piot, Sylvie Lortal, Valérie Gagnaire*
}

INRA, UMR1253, Science et Technologie du lait et de l'Euf F-35042 Rennes, France

Agrocampus Ouest, UMR1253, Science et Technologie du lait et de l'Oeuf, F-35042 Rennes, France

\section{A R T I C L E I N F O}

\section{Article history:}

Received 6 September 2011

Received in revised form 23 December 2011

Accepted 7 January 2012

Available online 18 January 2012

\section{Keywords:}

Swiss-type cheese

Mass spectrometry

Protein quantification

Lysis

Lactic acid bacteria

Isotopic labelling

\begin{abstract}
A B S T R A C T
Due to increasingly available bacterial genomes in databases, proteomic tools have recently been used to screen proteins expressed by micro-organisms in food in order to better understand their metabolism in situ. While the main objective is the systematic identification of proteins, the next step will be to bridge the gap between identification and quantification of these proteins. For that purpose, a new mass spectrometry-based approach was applied, using isobaric tagging reagent for quantitative proteomic analysis (iTRAQ), which are amine specific and yield labelled peptides identical in mass. Experimental Swiss-type cheeses were manufactured from microfiltered milk using Streptococcus thermophilus ITG ST20 and Lactobacillus helveticus ITG LH1 as lactic acid starters. At three ripening times (7, 20 and 69 days), cheese aqueous phases were extracted and enriched in bacterial proteins by fractionation. Each sample, standardised in protein amount prior to proteomic analyses, was: i) analysed by 2D-electrophoresis for qualitative analysis and ii) submitted to trypsinolysis, and labelled with specific iTRAQ tag, one per ripening time. The three labelled samples were mixed together and analysed by nano-LC coupled on-line with ESI-QTOF mass spectrometer. Thirty proteins, both from bacterial or bovine origin, were identified and efficiently quantified. The free bacterial proteins detected were enzymes from the central carbon metabolism as well as stress proteins. Depending on the protein considered, the quantity of these proteins in the cheese aqueous extract increased from 2.5 to 20 fold in concentration from day 7 to day 69 of ripening.
\end{abstract}

(c) 2012 Elsevier B.V. All rights reserved.

\section{Introduction}

Various bacteria - lactic acid bacteria, bifidobacteria, and dairy propionibacteria - are used in dairy processing for their technological or probiotic properties. Whole genome sequencing allows the detection of genes of technological interest but cannot inform us about their real expression in situ in food. For that purpose, transcriptomic, and above all, proteomic approaches are required.

They rely respectively on the extraction from food of bacterial RNA or bacterial proteins: RNA is fragile and bacterial proteins are in general in a dynamic range largely lower than the proteins of the food itself, which make both extractions complicated. Both approaches were developed to explore bacterial metabolism in cheeses: transcriptomic whole genome expression for lactococci in UF model cheeses, metabolic activity and free proteins released through lysis by thermophilic lactic starters in Swiss type cheeses (Cretenet et al., 2011; Falentin et al., 2012; Gagnaire et al., 2004, 2009). In these Swiss cheese, like in Cheddar (Sheehan et al., 2005) a mixture of lysed bacteria, and bacteria still metabolically active was observed.

\footnotetext{
* Corresponding author. Tel.: + 332234853 46; fax: + 33223485350 . E-mail address: valerie.gagnaire@rennes.inra.fr (V. Gagnaire).
}

Regarding proteins, the identification of the most predominant was achieved from 2D gel electrophoresis after an enrichment procedure, but until yet, without any quantification.

The last ten years have been rich in emergent quantitative technologies based either on gel electrophoresis or on chromatographic separations and mass spectrometry analysis. In order to circumvent the difficulty of quantifying proteins between gels, different mass spectrometry-based approaches have been developed using isotopic labelling for protein or peptide quantification. Based on liquid chromatographic separations, a number of advantages over 2DE can be distinguished. In contrast to proteins, peptides are more soluble, have similar size and are more easily ionised in the mass spectrometer ion source (Delahunty and Yates, 2005). Moreover, peptide separations by LC actually exhibit greater sensitivity, superior dynamic range, are more easily automated and faster than 2DE (O'Donnell et al., 2004).

The ICAT technology (Isotope Coded Affinity Tag) was the first isotopic labelling presented in the literature. It uses isotopic labelling of cysteine amino acid residues by a light or heavy tag containing biotinylated reagents differing by 8 Da (Gygi et al., 1999). However, the specificity of the ICAT labelling technique to cysteine amino acid residues is limited since about $15 \%$ of proteins do not contain any cysteine amino acid residues. Another technique available since 2004 
(Ross et al., 2004) is the iTRAQ ${ }^{\mathrm{TM}}$ (Isobaric Tagging for Relative and Absolute Quantitation) technique which is specific to primary amines found on the N-term end of the peptides and on the lysine and arginine side chains and permits relative quantitation of 2 to 8 samples simultaneously (Choe et al., 2007). In contrast to ICAT, peptides differentially labelled by iTRAQ appear as single peaks in MS thanks to the presence of a mass balancing moiety that render all labels isobaric. During MS/MS fragmentation, the isotope encoded reporter ions are released to allow relative quantification. The iTRAQ method has the double advantage of permitting the identification of the proteins and their quantification in a single LC-MS/MS run. The iTRAQ Method has been utilized in very different fields such as biomarker discovery (Fenselau, 2007), elucidation of cellular signalling pathways (Sui et al., 2007), post-translational modification analysis such as phosphorylation (Sachon et al., 2006), correlations between genomics and proteomics (Scherl et al., 2006), time course analysis (Cong et al., 2006; Jagtap et al., 2006), bacterial analysis (Chong et al., 2006; Danielsen et al., 2007), and membrane or sub-cellular analysis (Lund et al., 2007).

In the field of dairy products, few studies have yet been achieved using amine-reactive isobaric tagging reagents and mostly for studying protein expression in cows (Lippolis et al., 2006) or to quantify protein changes in milk fat globule membranes (Reinhardt and Lippolis, 2008).

In this work iTRAQ labelling was applied to proteins present in Swiss type cheese extracts at different points of the ripening, focusing in particular on bacterial proteins. Such a dynamic approach can contribute to a better insight on in situ starter metabolism.

\section{Materials and methods}

\subsection{Chemicals}

The following chemicals were used: Tris (Prolabo, WWR International, Fontenay sous Bois, France), DTT (plus one, GE Healthcare Bio-Sciences, Saclay, France), iodoacetamide (Sigma-Aldrich, Saint Quentin Fallavier, France), sequencing grade modified trypsin (Promega, Charbonnières, France), trifluoroacetic acid (TFA, Pierce, Touzart et Matignon, Vitry sur Seine, France), $\alpha$-cyano-4hydroxycinnamic acid matrix (CHCA, LaserBioLab, Sophia-Antipolis, France), acetonitrile Chromasolv ${ }^{\circledR}$ (Sigma-Aldrich), HPLC gradient grade water (Fisher scientific, Loughborough, Zeicestershire, UK), hydrochloric acid ( $\mathrm{HCl}$, Carlo Erba Reagenti, Chaussée du Vexin, France) formic acid and nitrilotriacetic acid (Fluka, Sigma-Aldrich, Saint Quentin Fallavier, France) and iTRAQ reagent kit for plasma applications (Applied Biosystems, Framingham, MA).

\subsection{Swiss-type cheese manufacture}

Mini Swiss-type cheeses were made in duplicate in a pilot plant (Pierre Guérin, Mauzé sur le Mignon, France). Fifty litres of raw milk were skimmed, then micro-filtered at $50{ }^{\circ} \mathrm{C}$ through a $1.4 \mu \mathrm{m}$ pore size Sterilox membrane (Société des Céramiques Techniques, Bazet, France) in order to eliminate contaminant flora from the milk (Trouvé et al., 1991). Milk was standardised to 0.83 ratio of fat to total nitrogen using cream heat treated at $90{ }^{\circ} \mathrm{C}$ for $45 \mathrm{~min}$. Controlled flora were inoculated with $10^{5} \mathrm{cfu} / \mathrm{mL}$ at $32{ }^{\circ} \mathrm{C}$ for each strain, as described below. The Streptococcus thermophilus starter strain, Pal ITG ST20 (Standa, Caen, France), was first cultured at $43^{\circ} \mathrm{C}$ for $5 \mathrm{~h}$ in 412 A Marstar commercial medium (Rhodia, Dangé Saint Romain, France) and inoculated at $10 \mathrm{~mL}$ per $10 \mathrm{~kg}$ of milk. The other starter strain Lactobacillus helveticus Pal ITG LH1 (Standa) was cultured at $42{ }^{\circ} \mathrm{C}$ for $5 \mathrm{~h}$ in PHAGEX commercial medium (Standa) and inoculated at $10 \mathrm{~mL}$ per $10 \mathrm{~kg}$ of milk. The main ripening flora represented by Propionibacterium freudenreichii subsp freudenreichii Pal ITG P23 (Standa) was directly inoculated into the microfiltered milk at $0.5 \mathrm{~g}$ of lyophilised strain per $10 \mathrm{~kg}$ of milk, to mimic the industrial process, corresponding to an average amount of $10^{4} \mathrm{cfu} / \mathrm{mL}$.

Milk was matured for $30 \mathrm{~min}$ at $32{ }^{\circ} \mathrm{C}$ and renneting was carried out at the same temperature with Maxiren (DSM, Lille, France) filtered through $0.22 \mu \mathrm{m}$. Clotting occurred 20 to $25 \mathrm{~min}$ after renneting. The cutting time was determined as $1 / 5$ of the clotting time. After cutting, the curd was gently stirred and heated from 32 to $45{ }^{\circ} \mathrm{C}$ at a rate of $0.5^{\circ} \mathrm{C} / \mathrm{min}$ and from 45 to $53^{\circ} \mathrm{C}$ at a rate of $1{ }^{\circ} \mathrm{C} /$ $\mathrm{min}$. Stirring was maintained for $15 \mathrm{~min}$ after heating. The curd grains were then drained off into the moulds and pressed at $12 \mathrm{~kg} / \mathrm{cheese}$ for $4 \mathrm{~h}$ at $45^{\circ} \mathrm{C}$. The mould was turned first at the end of pressing, and a second time $15 \mathrm{~h}$ after. It was then cooled to $12^{\circ} \mathrm{C}$. The Swiss-type wheels were demoulded and brined in a saturated $\mathrm{NaCl}$ solution (pH 5.2) at $12{ }^{\circ} \mathrm{C}$ for $1 \mathrm{~h}$. The wheels were then ripened first in a temperate room, $\left(12{ }^{\circ} \mathrm{C}\right.$, with relative humidity of $85 \%$ for 13 days), then in a warm room at $22^{\circ} \mathrm{C}$ with relative humidity of $75 \%$ until day 49 and finally in a cold room at $4{ }^{\circ} \mathrm{C}$ until the end of ripening at day 69 . Enumeration of the different bacteria in the cheeses and the physico-chemical analyses were performed according to the methods described by Thierry et al. (1998). Two independent cheeses were manufactured.

\subsection{Aqueous phase extraction}

Aqueous phases were extracted from cheese aliquots after 7, 20 and 69 days of ripening, according to the method of Kuchroo and Fox (1982): $10 \mathrm{~g}$ grated Swiss-type cheese were dispersed in $40 \mathrm{~g}$ of MilliQ water (Millipore, St Quentin en Yvelines, France) and blended with a high shear batch dispenser, ultra turrax (Janke and Henkel, Bioblock, Illkirch, France) for $3 \mathrm{~min}$ at 20,500 rpm and further stirred for $30 \mathrm{~min}$ at $40{ }^{\circ} \mathrm{C}$. Cheese samples were centrifuged at $10,000 \times \mathrm{g}$ for $10 \mathrm{~min}$ at $20^{\circ} \mathrm{C}$ on a Beckman J2-HS centrifuge equipped with a JA-20 rotor, to separate the aqueous phase from the pelleted caseins. The aqueous phases were successively filtered through Whatman paper 541 (Prolabo, Bruchet Dano, Rennes, France) then through 1.2 and $0.45 \mu \mathrm{m}$ pore size cellulose acetate membrane filters (Sartorius, Palaiseau, France). The cheese aqueous phases were concentrated about 10 times on Centriprep YM-10, 10 kDa MW cut off (Millipore) and stored at $-20{ }^{\circ} \mathrm{C}$ until use.

\subsection{Pre-fractionations steps}

In order to increase the concentration of bacterial proteins in the cheese aqueous phases prior to iTRAQ quantification, two prefractionation steps were used: affinity chromatography to selectively remove most of the lactoferrin, a major bovine protein present into the cheese aqueous extracts, and size exclusion chromatography to separate bacterial proteins from residual caseins and peptides derived from casein hydrolysis throughout ripening and from whey proteins. The affinity chromatography was performed on Hi Trap Blue $1 \mathrm{ml}$ (GE Healthcare) with the following buffers filtered on $0.45 \mu \mathrm{m}$ : A: $0.05 \mathrm{M}$ Tris- $\mathrm{HCl}, \mathrm{pH} 8$; $\mathrm{B}$ : $0.1 \mathrm{M} \mathrm{NaOH}$ and $\mathrm{C}: 2 \mathrm{M} \mathrm{KBr}$ and the following operating conditions: flow $1 \mathrm{ml} / \mathrm{min}$ and absorbance measured at $280 \mathrm{~nm}$ on an Äkta chain (GE Healthcare). The cheese aqueous phases were diluted to $3: 4$ cheese aqueous phase concentrate with $0.2 \mathrm{M}$ Tris- $\mathrm{HCl}$ pH 8 (i.e. $0.05 \mathrm{M}$ final). Two millilitres of the diluted sample were injected and the unloaded sample corresponding to aqueous phase depleted in lactoferrin was collected from 1 to 6.5 min of run with $100 \%$ A buffer. Proteins retained on Hi trap other than lactoferrin were also collected from the column with $100 \%$ B buffer for $3 \mathrm{~min}$. The fractions 1 and 2 were subsequently neutralised to $\mathrm{pH} 7$ with $1 \mathrm{M} \mathrm{HCl}$ and lyophilised on a Serail RP2V (SGD, Argenteuil, France). Lactoferrin was finally removed from the column by pulses of $B$ and $C$ buffers for $1 \mathrm{~min}$ each to rinse the column and remove all the lactoferrin (repeat 6 pulses). Then the column was re-equilibrated 
with A buffer for 10 min. Example of 2D gel before and after withdrawal of the lactoferrin is shown in Supplemental material.

For size exclusion chromatography, the cheese aqueous phases depleted in lactoferrin were solubilised in $50 \mathrm{mM}$ ammonium acetate, $\mathrm{pH} 7.0$, filtered on $0.22 \mu \mathrm{m}$ acetate cellulose filters and $2.5 \mathrm{~mL}$ samples were injected onto a Superdex 75 XK26/60 column (GE Healthcare) as described by Gagnaire et al. (2004). Isocratic elution was performed at $2 \mathrm{~mL} / \mathrm{min}$ in the same buffer at room temperature and detection was performed at $280 \mathrm{~nm}$. The required fractions from size exclusion chromatography were pooled and lyophilised for further use.

Total amino acid determination was performed on the three prefractionated cheese aqueous phase samples per cheese manufacture according to the method of Spackman et al. (1958) using a Biochrom 30 amino acid analyzer. Samples were dried and hydrolyzed under vacuum in $6 \mathrm{M} \mathrm{HCl}$ for $24 \mathrm{~h}$ at $110^{\circ} \mathrm{C}$ before chromatographic analysis. To quantify the cysteine and methionine residues, samples were first oxidized by performic acid and then hydrolyzed at $110{ }^{\circ} \mathrm{C}$ in $6 \mathrm{M} \mathrm{HCl}$, according to Moore (1963). Tryptophan was quantified from protein alkaline hydrolysates by ion exchange chromatography according to Hugli and Moore (1972).

\subsection{Two dimensional electrophoresis}

The proteins from the prefractionated aqueous cheese extracts were separated according to the conditions used by Gagnaire et al. (2004). Briefly, the first dimensional separation was carried out on IPG dry strips ( $\mathrm{pH} 4-7,18 \mathrm{~cm}$, GE healthcare) using an IPGPhor electrophoresis unit (GE healthcare). Lyophilised protein samples were suspended in $350 \mu \mathrm{L}$ of isoelectrofocusing (IEF) IPG sample buffer containing $7 \mathrm{M}$ urea, $2 \mathrm{M}$ thiourea, $25 \mathrm{mM}$ DTT, 4\% 3-[(3-chloramidopropyl) dimethylammonio]-1-propane-sulfonate (CHAPS), and $0.5 \%$ IPG-Buffer (GE healthcare), in order to load 500- $\mathrm{gg}$ eq bovine serum albumin per strip. After active rehydration at $50 \mathrm{~V}$ with samples $(350 \mu \mathrm{L})$ for $20 \mathrm{~h}$ at $20^{\circ} \mathrm{C}$ in the ceramic strip holder, the following voltage gradient was applied: $250 \mathrm{~V}$ for $1 \mathrm{~h}$; from 250 to $1000 \mathrm{~V}$ for $1 \mathrm{~h}$; from 1000 to $8000 \mathrm{~V}$ for $4 \mathrm{~h}$ and $8000 \mathrm{~V}$ for $3.75 \mathrm{~h}$. After IEF, strips were equilibrated for $8 \mathrm{~min}$ in a solution containing $50 \mathrm{mM}$ Tris-HCl, pH 6.2, $6 \mathrm{M}$ urea, 30\% (vol/vol) glycerol, $2 \%$ (wt/vol) SDS and $0.3 \%$ (wt/vol) DTT, followed by a second bath with the same solution but with $4.5 \%(\mathrm{wt} / \mathrm{vol})$ iodoacetamide instead of DTT. The second-dimensional separation was performed on an Ettan Dalt apparatus (GE Healtcare) using 10\% acrylamide separating gels without a stacking gel at a voltage of $50 \mathrm{~V}$ for $1.5 \mathrm{~h} \mathrm{~V}$ and $100 \mathrm{~V}$ for about $20 \mathrm{~h}$ until the tracking dye was within $1 \mathrm{~cm}$ of the gel bottom. Gels were fixed and stained with R250 Coomassie blue (Serva, Heildelberg, Germany).

\subsection{Trypsinolysis and iTRAQ labelling}

One hundred micrograms (based on amino acid determination, shown in Table 1) of proteins present in each sample were half diluted into $50 \mathrm{mM}$ Tris- $\mathrm{HCl}$ pH8.0, reduced with $10 \mathrm{mM}$ DTT for $1.5 \mathrm{~h}$ at $37^{\circ} \mathrm{C}$, and alkylated with $55 \mathrm{mM}$ iodoacetamide for $1 \mathrm{~h}$ at $37^{\circ} \mathrm{C}$ in the dark. Samples were dialysed with acetate cellulose membrane

Table 1

Total amino acid concentration of the different Swiss-type cheese aqueous phases prefractionated prior to iTRAQ labelling for the three ripening stages.

\begin{tabular}{llc}
\hline \multirow{2}{*}{$\begin{array}{c}\text { Ripening stage } \\
\text { (day) }\end{array}$} & \multicolumn{2}{l}{ Total amino acid concentration $\left(\mathrm{g} \cdot \mathrm{kg}^{-1}\right)$} \\
\cline { 2 - 3 } & Cheese A & Cheese B \\
\hline 7 & 1.652 & 1.824 \\
20 & 1.714 & 1.889 \\
69 & 2.357 & 2.464 \\
\hline
\end{tabular}

dialysis (cut-off $2000 \mathrm{Da}$, SpectraPor) against $3 \times 3 \mathrm{~L}$ of MilliQ water at $4{ }^{\circ} \mathrm{C}$ for $48 \mathrm{~h}$ to eliminate residual presence of ammonium acetate from size exclusion chromatography buffer, and concentrated by speedvac prior to digestion. The proteins were then solubilised with $60 \mu \mathrm{L}$ of sample buffer from the iTRAQ reagent kit for plasma applications (Applied Biosystems, Framingham, MA).

Prefractionated proteins were hydrolysed with sequencing grade modified trypsin (Promega, Charbonnières, France) at $1 \mu \mathrm{g} / \mathrm{sample}$ overnight at $40{ }^{\circ} \mathrm{C}$. The reaction was stopped by adding $20 \mu \mathrm{L}$ of $5 \%$ trifluoroacetic acid (TFA, Pierce, Touzart et Matignon, Vitry sur Seine, France).

Thirty five micrograms of prefractionated protein from cheese samples at each ripening time were labelled with iTRAQ reagents as described by the manufacturer (Applied Biosystems) with reagents $114,115,116$ added to samples corresponding to 7, 20 and 69 days of ripening respectively. After a $1 \mathrm{~h}$ incubation period, excess labelling reagent was inactivated with $100 \mu \mathrm{L}$ LC grade water and labelled samples were combined and dried with Speedvac. Combined samples were then solubilised in solution B (97.9\% LC grade water (Fisher Scientific), $2 \%$ acetonitrile (Chromanorm), $0.08 \%$ formic acid (Fluka), and $0.01 \%$ TFA (Sigma Aldrich)) to a final concentration of $1 \mu \mathrm{g} / \mathrm{L}$ prior to chromatographic separation.

\subsection{Chromatographic and Mass Spectrometric Analyses by QTOF MS/MS}

The labelled samples ( $10 \mu \mathrm{L})$ were first applied onto a micro-precolumn cartridge $\mathrm{C}_{18}$ PepMap (LC Packings). Before each reversephase elution, this cartridge was rinsed with solution A ( $2 \%$ acetonitrile and $0.1 \%$ trifluoroacetic acid in HPLC grade water) for $5 \mathrm{~min}$ at $20 \mu \mathrm{L} / \mathrm{min}$. Thereafter, the valve was automatically switched in order to couple on-line the cartridge and the reverse-phase column $\mathrm{C}_{18}$ PepMap 100 (LC Packings, $3 \mu \mathrm{m}, 100 \AA$ A, $75 \mu \mathrm{m}$ i.d. $\times 15 \mathrm{~cm}$ ). The peptides were then separated using a linear gradient of buffer B ( $2 \%$ acetonitrile, $0.08 \%$ formic acid and 0.01\% TFA in HPLC grade water) and C (95\% acetonitrile, $0.08 \%$ formic acid and 0.01\% TFA) from $10 \%$ to $90 \%$ of buffer $C$ in $120 \mathrm{~min}$. The online separated peptides were concomitantly analysed by ESI Q-TOF and automatically spotted onto MALDI targets using a LC-MALDI deposition device (Probot, Dionex). The system was configured to perform a post-column split of the $250 \mathrm{~nL} / \mathrm{min}$ flow rate such that $50 \mathrm{~nL} / \mathrm{min}$ were introduced to the micro-electrospray source of the mass spectrometer while $200 \mathrm{~nL} / \mathrm{min}$ were delivered into the online Probot. For each spot collected on the MALDI plate, $200 \mathrm{~nL}$ of eluted peptides were coaxially mixed with $1 \mu \mathrm{L}$ of $\alpha$-cyano-4-hydroxycinnamic acid (CHCA) matrix at $10 \mathrm{~g} / \mathrm{L}$ diluted $1: 5$ with a solution containing $0.1 \% \mathrm{TFA}, 70 \%$ acetonitrile and supplemented with $10 \mathrm{mM}$ nitrilotriacetic acid in order to reduce background noise and enhance peptide signal during MALDI acquisition (Kim et al., 2005). The mixture was then deposited as discrete spots on MALDI targets. Each spot represented an aliquot collected every $60 \mathrm{~s}$ during the $120 \mathrm{~min}$ of reversed phase effective gradient. In order to maximise the number of peptides identified, three successive injections were performed for each one of the two cheese replicates thus resulting in 6 injections and chromatographic runs and in 12 mass spectrometry analyses in total (6 ESI and 6 MALDI) (Chong et al., 2006).

All mass spectra were performed using a hybrid quadrupole time of flight (Q/TOF) mass spectrometer QStar XL (MDS Sciex, Toronto, Canada). The instrument was calibrated for both MALDI and ESI with a multi-point calibration using fragment ions that resulted from the collision-induced decomposition (CID) of a peptide from $\beta$-casein, i.e. $\beta-C N$ (193-209).

\subsubsection{ESI-Q/TOF analysis}

The online separated peptides were analysed by ESI Q-TOF in positive ion mode. A voltage of around $3.5 \mathrm{kV}$ was applied to the microelectrospray ion source (Proxeon Biosystems A/S, Odense, Denmark). 
MS and MS/MS data were acquired in continuum mode. Data-direct analysis was employed to perform MS/MS analysis on $1^{+}$to $3^{+}$ charged precursor ions. Precursor selection was based upon ion intensity, charge state and if the precursor had been previously selected for fragmentation, they were excluded. Spectra were collected in the selected mass range $450-2000 \mathrm{~m} / z$ for MS and $60-2000 \mathrm{~m} / z$ for MS/ MS spectra. The mass spectrometer was operated in data-dependent mode automatically switching between MS and MS/MS acquisition using Analyst QS 1.1 software when the intensity of the ions was above $10 \mathrm{cps}$, with varying collision energy according to the ion charge and $\mathrm{m} / \mathrm{z}$. Compared with routine proteomic analysis, the collision energies used were increased by $10 \%$ to allow an efficient liberation of the reporter ions as described by Wiese et al. (2007). In addition, the IDA extensions II script was set to 2 repetitions before dynamic exclusion and every 6 cycles the ion nearest to 15 cps was selected for fragmentation. These settings ensured examination of low abundance as well high abundance ions.

\subsubsection{MALDI-Q/TOF analysis}

For MALDI experiments, samples co-crystallized with CHCA were transferred to the mass spectrometer and ionised at $17 \mu \mathrm{J}$ with a nitrogen laser beam $(\lambda=337 \mathrm{~nm})$ at a frequency of $20 \mathrm{~Hz}$. MALDI plates were automatically analysed using oMALDI Xpert 2.0 software and enhanced IDA functionality. Typically oMALDI Xpert 2.0 software treats each sample plate as an LC-MALDI workflow generating a global MS peak list. The more representative mono-charged ions were then submitted to fragmentation from the spot where they demonstrated their maximum intensity (typically 5 to $10 \mathrm{MS} / \mathrm{MS}$ per spot). As for ESI analysis, a $m / z$ dependent collision energy was used. MS spectra were collected from $\mathrm{m} / \mathrm{z} 600$ to $\mathrm{m} / \mathrm{z} 3000$ and MS/MS spectra were collected from $\mathrm{m} / \mathrm{z} 60$ to $\mathrm{m} / \mathrm{z} 2000$.

\subsubsection{Database search and protein identification and quantification}

All data (MS and MS/MS) were submitted to MASCOT (v.2.2) for identification and quantification. The search was performed against a homemade database dealing with cheese organisms which represents a portion of the Swissprot database (http://www.expasy.org/, 24th September 2007). One missed trypsin cleavage was allowed and 2 variable modifications were selected: deamidation on Gln and Asn and oxidation on Met. The peptide mass tolerance was set to 0.3 Da for MS and 0.15 Da for MS/MS. The quantification method in Mascot 2.2 used a weighted protein ratio type, an automatic outlier removal and no normalization. For each protein identified, a minimum of at least two unique matching peptides with a score above the MASCOT identity threshold corresponding to a p-value inferior to 0.05 was considered as a prerequisite for protein validation with a high degree of confidence.

\subsection{Statistical analysis}

In order to confirm that there was no difference between the quantification results obtained during ESI and MALDI analysis, a Student's $t$ test for dependent samples was used to assess statistical difference between both groups. It was performed using the $\log _{10}$ transformations of iTRAQ quantification ratios. Ten proteins were used in this test; they were chosen with available quantification values for each one of the 12 analyses. The mean ESI and the mean MALDI quantification values were compared for each one of these ten proteins and for both iTRAQ ratios $114 / 116$ and $115 / 116$. The differences between mean quantification values obtained in ESI and MALDI were not statistically significant $(p>0.05$, data not shown) and therefore the results obtained with both ion sources were grouped for global analysis in MASCOT 2.2 for database search and protein quantification.

A Student's t-test for independent samples was used to determine if cheese replicates showed significantly different iTRAQ quantification ratios. The same set of ten proteins as in the previous $t$-test was used for this statistical analysis. The differences between mean quantification values obtained for 5 out of 10 proteins between both cheese replicates were statistically significant ( $\mathrm{p}<0.05$, data not shown) and it was decided to treat these cheese replicates independently.

\section{Results}

\subsection{Microbiological and physico-chemical analyses of Swiss-type cheeses}

The conditions of manufacture of Swiss-type cheese were chosen in order to limit the growth of secondary ripening flora, mainly represented by facultatively heterofermentative lactobacilli (Thierry et al., 1998). Consequently after microfiltration, the total milk flora of both cheeses manufactured was reduced from $3.2 \times 10^{5} \mathrm{cfu} / \mathrm{mL}$ milk to less than $20 \mathrm{cfu} / \mathrm{mL}$ and with potential contaminating flora such as coliforms less than $10 \mathrm{cfu} / \mathrm{mL}$ of milk.

Maximal growth of thermophilic starters occurred as usually at the end of the pressing step ( $\sim 10^{9} \mathrm{cfu} / \mathrm{g}$ for both species). After 7 days of ripening, ITG ST20 and ITG LH1 strains counts were $1.0 \times 10^{7}$ and $1.4 \times 10^{7} \mathrm{cfu} / \mathrm{g}$ of cheese for cheese $\mathrm{A}$ and $7.1 \times 10^{8}$ and $6.1 \times 10^{8} \mathrm{cfu} / \mathrm{g}$ of cheese for cheese B. Thereafter, $S$ thermophilus and $L$ helveticus counts decreased continuously throughout ripening down to $8.9 \times 10^{4} \mathrm{cfu} / \mathrm{g}$ for cheese A and $3.3 \times 10^{6} \mathrm{cfu} / \mathrm{g}$ for cheese B for $L$ helveticus while $S$ thermophilus was no longer detected on M17 agar plates at the end of the ripening for both cheeses. In agreement with previous results, $P$ freudenreichii ITG P23 grew during warm room ripening and reached $2.3 \times 10^{9}$ and $3 \times 10^{9} \mathrm{cfu} / \mathrm{g}$ for cheeses $\mathrm{A}$ and B respectively (Thierry et al., 1998).

Heterofermentative lactobacilli count did not exceed $10^{2} \mathrm{cfu} / \mathrm{g}$ of cheese during manufacture. The composition of the cheeses at day one and at the end of ripening fitted well with the data already published on Swiss-type cheeses (Bachmann et al., 1997; Beuvier et al., 1997; Thierry et al., 1998).

\subsection{Release of the proteins in cheese aqueous phase visualised by $2 D$} PAGE

Proteins obtained after the prefractionation steps, were resolved by 2D-PAGE in the $\mathrm{pH}$ range 4 to 7 and visualised following Coomassie blue staining (Fig. 1). Increase in number and intensity of about 150 protein spots were found when $0.5 \mathrm{mg}$ of protein were loaded onto the gel. Proteins identified in previous work were mainly intracellular bacterial proteins from $L$ helveticus (Phosphoglycerate kinase A8YUE3, $60 \mathrm{kDa}$ chaperonin A4ZGY6 and L-lactate dehydrogenase A4UAE7) and $S$ thermophilus (60 kDa chaperonin Q5M1M9, $\beta$ galactosidase P23989) as well as bovine proteins from whey (serum albumin P02769). Due to in gel variability for example for bovine serum albumin although this protein is not degraded during ripening and to avoid preparing a numerous set of gels, we used the iTRAQ labelling to quantify the protein released as shown below.

\subsection{Protein identification and quantification by $i T R A Q$}

In our study, the nanoLC post-column flow was split to use the complementary ESI and MALDI ionisation sources in a single injection. While $50 \mathrm{~nL} / \mathrm{min}$ was sent toward the ESI source for online acquisition on a Q/TOF (QSTAR XL, Sciex), $200 \mathrm{~nL}$ were directed toward an automatic collection device (Probot, Dionex) and mixed with CHCA matrix to deposit sample on a MALDI plate for subsequent analysis. The originality of this experimental setup is that it allows data from ESI and MALDI sources to be collected using the same Q/ TOF mass spectrometer. The data originating from the 3 successive injections of one biological sample and collection of data with ESI and MALDI sources were merged in MASCOT prior to initiating the database search. This was allowed because no significant differences in 

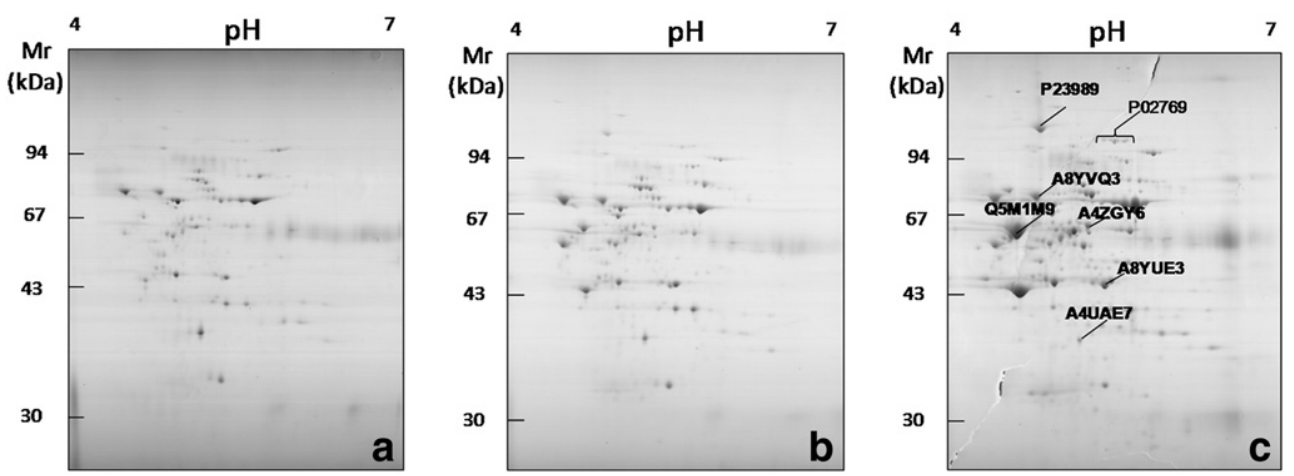

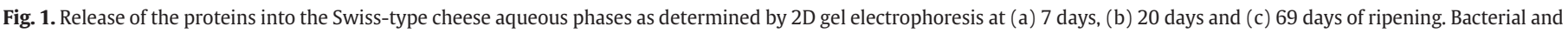
bovine proteins identified in a previous study are labelled in bold and normal typing respectively.

the quantification results were obtained regardless of the ion source used. Two potential benefits were obtained: acquisition time shortening, and generation of both types of data with minimum sample consumption. The combination of the data obtained with both ionisation sources resulted in increased proteome coverage and therefore improved the confidence in identification and quantification results (data not shown). The majority of geometric standard deviation calculated with peptide ratios obtained across the three successive injections and acquired with both ionisation sources ESI and MALDI were inferior to 1.25 for samples from a normal distribution demonstrating a good reproducibility of the ratios obtained and therefore validating the settings used in this study.

For each protein identified, a minimum of two quantification values from valid peptides per protein was required for the ratios to be considered certain and displayed. Thirty and 34 proteins respectively were identified and quantified for cheese A and cheese B (Tables 2 and 3). 18 and 19 proteins were of bovine origin, whereas 12 and 15 bacterial proteins were identified and quantified in cheeses $A$ and $B$ respectively. Among the identified proteins, 15 bovine proteins were common to both cheeses; one protein from $S$. thermophilus and 9 from $L$ helveticus were found in common for both cheeses.

The iTRAQ relative quantification gives results which are presented as ratios. In order to measure and display standard deviation on these quantification results, we worked in the logarithmic space and used the geometric standard deviation calculation. The results are represented as ratios, compared to 69 days of ripening (Fig. 2). The geometric standard deviation reported are calculated via Mascot 2.2 across a set of different injections measured in mass spectrometry with ESI and MALDI sources therefore resulting in 6 different mass spectrometry acquisitions. Thus, these standard deviations highlight reproducibility of this technique and encompass the successive chromatographic injections as well as reproducibility across the two ion sources.

Two distinct populations of quantified proteins can be distinguished according to their bacterial or bovine origin (Fig. 2, Tables 2 and 3). Indeed, except for the protein phosphoglycerate kinase (A8YUE3) of $L$ helveticus in cheese B, the only iTRAQ ratios around unity or superior to unity for D7/D69 or D20/D69 are obtained for protein of bovine origin.

Bovine proteins were the only ones displaying a constant concentration or a decrease in concentration in the aqueous phase of cheese during ripening. These discrepancies in concentration for proteins that are naturally in milk may be explained by the fact that the prefractionation of our sample was intended to delete some of these bovine proteins in order to be able to detect bacterial proteins. This was effective in particular for lactoferrin which was removed by affinity chromatography (Supplemental material) and for caseins, $\beta$ lactoglobulin and $\alpha$-lactalbumin by gel filtration step. As $\beta$-casein (P02666) can be present in the cheese aqueous phase due to weaker interactions with the other caseins in the cheese matrix, greater variability was observed between both cheeses for this protein. Nevertheless, most bovine proteins showed iTRAQ ratios superior to unity which suggests a decreasing concentration for these proteins within the cheese aqueous extract during ripening. This further validates the clear trend observed for bacterial proteins for which a net increase in bacterial protein concentrations is observed throughout ripening

Proteins of bacterial origin are grouped and display the highest increase in concentration (i.e. lowest values of iTRAQ ratios) between day 7 and day 69 of ripening. Apart from the phosphoglycerate kinase (A8YUE3) of L. helveticus identified in cheese A, all bacterial proteins were subjected to a minimum 2.5 fold increase in concentration from day 7 to day 69 of ripening. Across both cheese replicates, the enolase protein (A8YUV4) from $L$. helveticus showed a 20 fold increase in concentration from day 7 to day 69 of ripening. This protein concentration does not increase significantly before day 20 of ripening as it still shows an increase superior to 10 fold between day 20 and day 69 for both cheese replicates. Four and eight other proteins respectively showed an increase of concentration from day 7 to day 69 superior to 5 fold in cheeses A and B. Most bacterial proteins manifest a small increase in concentration from day 7 to day 20 as evidenced by a superior D20/D69 ratio compared to the D7/D69. Nevertheless, five and four proteins respectively for cheeses A and B still display a fivefold increase in concentration from day 20 to day 69 of ripening, all of these being of bacterial origin.

\section{Discussion}

This is the first time, to the best of our knowledge, that 30 proteins, both from bacterial and bovine origin, were identified and efficiently quantified in the cheese matrix during ripening by ITRAQ technology. The quantification of bacterial proteins released into the cheese aqueous phase was challenging because of the great dynamic range of protein concentration between milk and bacterial proteins. To decrease this dynamic range we simplified the proteome before labelling through pre-fractionation steps, which included one more step than the protocol used previously (Gagnaire et al., 2004) in order to withdraw lactoferrin by affinity chromatography. However, complexity remained and with regards to the chromatographic strategy used, many peptides were likely not detected due to the sensitivity of our instrument. In fact, tandem mass spectrometry instrument focuses on the most abundant ions and need several seconds to obtain enough data to generate useful peptide spectra (Reinhardt and Lippolis, 2006). Other reasons for the low number of proteins identified could be: low protein abundance, co-elution of peptides with other highly abundant peptides, solubility problems in our extraction, or the protein simply has not yet been sequenced in cow (Lippolis et al., 2006) or not yet implemented in the Swissprot database at the time of this study. Some proteins were identified but they were 
Table 2

Proteins identified during iTRAQ analysis of the aqueous phase of cheese A.

\begin{tabular}{|c|c|c|c|c|c|c|c|c|c|c|c|c|}
\hline \multirow{2}{*}{$\begin{array}{l}\text { Species } \\
\text { origin }\end{array}$} & \multirow{2}{*}{$\begin{array}{l}\text { Accession } \\
\text { number }\end{array}$} & \multirow[t]{2}{*}{ Description } & \multirow[t]{2}{*}{ Score $^{\text {b }}$} & \multirow{2}{*}{$\begin{array}{l}\text { Percent } \\
\text { coverage }^{c}\end{array}$} & \multirow{2}{*}{$\begin{array}{l}\text { Protein } \\
\text { Mass } \\
(\mathrm{kDa})^{\mathrm{d}}\end{array}$} & \multicolumn{7}{|c|}{ Quantitation summary for protein } \\
\hline & & & & & & $\begin{array}{l}\text { D7/ } \\
\text { D69 }\end{array}$ & $\begin{array}{l}\mathrm{N}(\mathrm{D} 7 / \\
\mathrm{D} 69)^{\mathrm{e}}\end{array}$ & $\begin{array}{l}\text { SD }(D 7 / D 69)^{f} \\
(\text { geo })\end{array}$ & $\begin{array}{l}\text { D20/ } \\
\text { D69 }\end{array}$ & $\begin{array}{l}\mathrm{N}(\mathrm{D} 20 / \\
\mathrm{D} 69)^{\mathrm{e}}\end{array}$ & $\begin{array}{l}\text { SD }(\text { D20/D69 })^{f} \\
(\text { geo })\end{array}$ & $\begin{array}{l}\text { Fold change from } \\
\text { D7 to D69 }\end{array}$ \\
\hline L. helveticus & A4ZGY6 & $60 \mathrm{kDa}$ chaperonin & 1987 & 33.5 & 63.8 & 0.2 & 47 & 1.1 & 0.3 & 54 & NN & $5.9 \uparrow$ \\
\hline L. helveticus & A8YV23 & Pyruvate kinase & 798 & 8.0 & 69.2 & 0.1 & 22 & 1.2 & 0.2 & 21 & 1.1 & $8.3 \uparrow$ \\
\hline L. helveticus & A8YUE3 & $\begin{array}{l}\text { Phosphoglycerate } \\
\text { kinase }\end{array}$ & 507 & 18.1 & 48.6 & 0.6 & 20 & 1.1 & 0.7 & 19 & 1.1 & $1.8 \uparrow$ \\
\hline L. helveticus & A8YUV4 & Enolase & 492 & 19.6 & 51.1 & 0.1 & 17 & 1.1 & 0.1 & 18 & 1.3 & $20.0 \uparrow$ \\
\hline L. helveticus & A8YUI5 & $\begin{array}{l}\text { Glucose-6-phosphate } \\
\text { isomerase }\end{array}$ & 409 & 17.8 & 54.1 & 0.2 & 17 & 1.2 & 0.3 & 17 & 1.2 & $4.8 \uparrow$ \\
\hline L. helveticus & A4UAE7 & L-lactate dehydrogenase & 271 & 16.4 & 38.9 & 0.2 & 10 & 1.4 & 0.5 & 12 & 1.2 & $4.8 \uparrow$ \\
\hline L. helveticus & A4ZH05 & $\begin{array}{l}\text { Inosine- } 5^{\prime} \text { - } \\
\text { monophosphate } \\
\text { dehydrogenase }\end{array}$ & 237 & 15.3 & 43.3 & 0.3 & 10 & 1.3 & 0.4 & 10 & 1.5 & $3.6 \uparrow$ \\
\hline L. helveticus & Q7WTB1 & $\begin{array}{l}\text { UDP-glucose } 4 \text { - } \\
\text { epimerase }\end{array}$ & 191 & 9.4 & 41.2 & - & 1 & - & 0.2 & 4 & NN & - \\
\hline L. helveticus & A4ZGV9 & $\begin{array}{l}\text { Glyceraldehyde 3- } \\
\text { phosphate dehydrogenase }\end{array}$ & 159 & 13.9 & 40.0 & 0.2 & 4 & 1.6 & 0.2 & 6 & 3.1 & $6.3 \uparrow$ \\
\hline L. helveticus & A4ZGV7 & $\begin{array}{l}\text { Fructose-1.6- } \\
\text { biphosphate aldolase }\end{array}$ & 124 & 12.2 & 37.8 & 0.2 & 7 & 1.3 & 0.3 & 9 & 1.4 & $4.8 \uparrow$ \\
\hline S. thermophilus & Q5M2M7 & $\begin{array}{l}\text { Glyceraldehyde-3-phosphate } \\
\text { dehydrogenase }\end{array}$ & 755 & 27.8 & 38.9 & 0.4 & 25 & 1.1 & 0.4 & 25 & NN & $2.6 \uparrow$ \\
\hline S. thermophilus & Q5M0M5 & Enolase & 344 & 20.5 & 50.7 & 0.1 & 9 & 1.2 & 0.2 & 11 & NN & $7.7 \uparrow$ \\
\hline Bos taurus & Q2UVX4 & Complement C3 & 2362 & 29.4 & 206.5 & 0.5 & 91 & $\mathrm{NN}$ & 0.6 & 92 & 1.1 & $2.1 \uparrow$ \\
\hline Bos taurus & P80195 & Lactophorin & 772 & 38.6 & 19.2 & 1.1 & 46 & 1.8 & 1.4 & 46 & NN & $1.1 \downarrow$ \\
\hline Bos taurus & P80457 & $\begin{array}{l}\text { Xanthine dehydrogenase/ } \\
\text { oxidase }\end{array}$ & 1678 & 20.9 & 161.8 & 0.6 & 80 & NN & 0.6 & 80 & 1.1 & $1.8 \uparrow$ \\
\hline Bos taurus & Q95114 & Lactadherin & 1609 & 35.8 & 51.0 & 0.9 & 62 & NN & 1.1 & 62 & NN & $1.1 \uparrow$ \\
\hline Bos taurus & P24627 & Lactotransferrin (lactoferrin) & 1406 & 28.8 & 88.1 & 0.5 & 58 & NN & 0.4 & 56 & NN & $2.1 \uparrow$ \\
\hline Bos taurus & P81265 & $\begin{array}{l}\text { Polymeric-immunoglobulin } \\
\text { receptor }\end{array}$ & 1116 & 24.3 & 90.8 & 1.0 & 44 & NN & 1.2 & 46 & 1.1 & 1.0 \\
\hline Bos taurus & A4IFIO & MGC151892 protein & 639 & 16.6 & 27.0 & 0.8 & 14 & 1.2 & 1.1 & 14 & 1.1 & $1.3 \uparrow$ \\
\hline Bos taurus & P26201 & Platelet glycoprotein 4 & 599 & 18.0 & 58.5 & 1.0 & 22 & 1.1 & 1.1 & 23 & NN & 1.0 \\
\hline Bos taurus & P02754 & $\beta$-lactoglobulin & 475 & 30.9 & 22.7 & 1.4 & 12 & 1.2 & 1.2 & 12 & 1.2 & $1.4 \downarrow$ \\
\hline Bos taurus & A5D7Q2 & $\begin{array}{l}\text { Putative uncharacterized } \\
\text { protein }\end{array}$ & 416 & 8.4 & 56.0 & 0.9 & 12 & 1.1 & 1.1 & 12 & 1.1 & $1.1 \uparrow$ \\
\hline Bos taurus & P02666 & $\beta$-casein & 332 & 15.6 & 27.0 & 2.1 & 12 & NN & 4.5 & 12 & 1.6 & $2.1 \downarrow$ \\
\hline Bos taurus & P80025 & Lactoperoxidase & 297 & 12.9 & 87.4 & 0.8 & 15 & 1.1 & 0.7 & 15 & 1.2 & $1.3 \uparrow$ \\
\hline Bos taurus & P18892 & $\begin{array}{l}\text { Butyrophilin subfamily } 1 \\
\text { member A1 }\end{array}$ & 206 & 11.8 & 63.5 & 1.4 & 8 & 1.2 & 1.4 & 10 & 1.3 & $1.4 \downarrow$ \\
\hline Bos taurus & P02662 & $\alpha_{\mathrm{S} 1}$-casein & 184 & 13.1 & 26.9 & 1.1 & 7 & 1.3 & 1.0 & 7 & 1.1 & $1.1 \downarrow$ \\
\hline Bos taurus & P02769 & Serum albumin & 173 & 7.9 & 80.0 & 2.0 & 6 & 1.4 & 1.7 & 6 & 1.3 & $2.0 \downarrow$ \\
\hline Bos taurus & Q27960 & $\begin{array}{l}\text { Na-dependent phosphate } \\
\text { transport protein } 2 \mathrm{~B}\end{array}$ & 114 & 3.8 & 83.3 & 1.4 & 4 & 1.1 & 1.6 & 4 & 1.4 & $1.4 \downarrow$ \\
\hline Bos taurus & P02663 & $\alpha_{\mathrm{S} 2}$-casein & 104 & 6.3 & 29.9 & 0.6 & 6 & 1.4 & 0.7 & 6 & 1.4 & $1.7 \uparrow$ \\
\hline Bos taurus & Q09139 & $\begin{array}{l}\text { Fatty acid-binding protein. } \\
\text { brain }\end{array}$ & 87 & 18.3 & 16.3 & 2.9 & 3 & 1.4 & 2.2 & 3 & 1.7 & $2.9 \downarrow$ \\
\hline
\end{tabular}

Values in this table represent the average values of 3 successive injections analysed in ESI and MALDI as given by MASCOT via merging of the 6 data files.

a Accession number of the protein in the SwissProt/Uniprot database.

b Protein score is the sum of the highest ions score for each distinct sequence.

c Percent coverage determines the percent of the residues in each protein sequence that have been identified.

d Value of molecular mass of the protein from the SwissProt/Uniprot database.

e $\mathrm{N}$ represents the number of iTRAQ peptide ratios that contributed in the calculation of the protein average ratio.

f $\mathrm{SD}$ (geo) represents the geometric standard deviation on the ratio; if the peptide match ratios do not appear to be a sample from a normal distribution. NN (not normal) is displayed.

not further quantified, because the reporter ions were not detected and therefore no quantitation data could be obtained.

Regarding the bovine proteins identified and quantified in this study, we observed that those abundant in milk such as caseins, whey proteins, i.e. $\beta$-lactoglobulin, serum albumin, lactoferrin, were partly or mostly removed from the cheese aqueous phases through the different pre-fractionation steps. Nevertheless, some other proteins considered as quantitatively minor in milk can be retained into the curd during cheese manufacture such as xanthine oxidase (P80457) with milk concentration range $70-200 \mathrm{mg} / \mathrm{L}$ of milk and lactoperoxidase (P80025) $30 \mathrm{mg} / \mathrm{L}$ (Kussendrager and van Hooydonk, 2000) and other minor proteins with concentrations below $1 \mathrm{mg} / \mathrm{L}$. As a result, a large dynamic range of concentration in proteins could hinder the identification and quantification of the less abundant proteins. As expected, bovine protein concentration only weakly changed from D7 to D69 in both cheeses since they are trapped in the curd during cheese manufacture. Proteins such as caseins are degraded by the enzymes of the microflora and peptides resulting from their degradation can be "over" quantified as shown from the 6 fold increase of $\beta$-casein between D7 and D69. For the other bovine proteins, the fold change below 2 observed for 13 out of the 18 bovine proteins quantified in cheese A and 15 out of the 19 proteins in cheese B confirmed their lower degradation as these proteins which contain disulphide bonds and globular structure are almost not degraded by the enzymes of the microflora.

Bacterial proteins regardless of their origin, i.e. $S$ thermophilus or $L$ helveticus, were progressively released into the cheese matrix 
Table 3

Proteins identified during iTRAQ analysis in a fraction of the aqueous phase of cheese B.

\begin{tabular}{|c|c|c|c|c|c|c|c|c|c|c|c|c|}
\hline \multirow[t]{2}{*}{ Species origin } & \multirow{2}{*}{$\begin{array}{l}\text { Accession } \\
\text { number }\end{array}$} & \multirow[t]{2}{*}{ Description } & \multirow[t]{2}{*}{ Score $^{\mathrm{b}}$} & \multirow{2}{*}{$\begin{array}{l}\text { Percent } \\
\text { coverage }^{c}\end{array}$} & \multirow{2}{*}{$\begin{array}{l}\text { Protein } \\
\text { mass }^{\mathrm{d}} \\
(\mathrm{kDa})\end{array}$} & \multicolumn{7}{|c|}{ Quantitation summary for protein } \\
\hline & & & & & & $\begin{array}{l}\text { D7/ } \\
\text { D69 }\end{array}$ & $\begin{array}{l}\mathrm{N}(\mathrm{D} 7 / \\
\mathrm{D} 69)^{\mathrm{e}}\end{array}$ & $\begin{array}{l}\text { SD }(D 7 / D 69)^{f} \\
(\text { geo })\end{array}$ & $\begin{array}{l}\text { D20/ } \\
\text { D69 }\end{array}$ & $\begin{array}{l}\mathrm{N}(\mathrm{D} 20 / \\
\mathrm{D} 69)^{\mathrm{e}}\end{array}$ & $\begin{array}{l}\text { SD (D20/D69) } \\
(\text { geo })\end{array}$ & $\begin{array}{l}\text { Fold change from } \\
\text { D7 to D69 }\end{array}$ \\
\hline L. helveticus & A4ZGY6 & $60 \mathrm{kDa}$ chaperonin & 964 & 33.5 & 63.8 & 0.3 & 39 & 1.1 & 0.4 & 39 & 1.1 & $3.3 \uparrow$ \\
\hline L. helveticus & A8YV23 & Pyruvate kinase & 909 & 8.0 & 69.2 & 0.1 & 21 & 1.2 & 0.2 & 24 & NN & $8.3 \uparrow$ \\
\hline L. helveticus & A8YUV4 & Enolase & 413 & 19.6 & 51.1 & 0.1 & 11 & 1.6 & 0.1 & 12 & 1.4 & $20.0 \uparrow$ \\
\hline L. helveticus & A8YUI5 & $\begin{array}{l}\text { Glucose-6-phosphate } \\
\text { isomerase }\end{array}$ & 287 & 12.4 & 54.1 & 0.2 & 10 & 1.2 & 0.2 & 11 & 1.5 & $6.7 \uparrow$ \\
\hline L. helveticus & A4UAE7 & L-lactate dehydrogenase & 231 & 18.9 & 38.9 & 0.2 & 12 & 1.3 & 0.3 & 13 & 1.2 & $4.3 \uparrow$ \\
\hline L. helveticus & A4ZH05 & $\begin{array}{l}\text { Inosine-5'-monophosphate } \\
\text { dehydrogenase }\end{array}$ & 145 & 12.6 & 43.3 & 0.1 & 7 & 1.5 & 0.4 & 4 & 1.0 & $8.3 \uparrow$ \\
\hline L. helveticus & A8YUE3 & Phosphoglycerate kinase & 138 & 4.5 & 48.6 & 0.7 & 7 & 1.3 & 1.5 & 7 & 1.2 & $1.5 \uparrow$ \\
\hline L. helveticus & A4ZGV7 & $\begin{array}{l}\text { Fructose-1.6-biphosphate } \\
\text { aldolase }\end{array}$ & 100 & 8.9 & 37.8 & 0.2 & 6 & 1.2 & 0.1 & 6 & 1.3 & $6.3 \uparrow$ \\
\hline L. helveticus & A8YVQ3 & $\begin{array}{l}\text { Heat shock protein } \\
\text { DNAJ }\end{array}$ & 52 & 4.9 & 75.4 & 0.2 & 4 & 1.5 & 0.3 & 3 & 1.3 & $5.3 \uparrow$ \\
\hline L. helveticus & A4ZGV9 & $\begin{array}{l}\text { Glyceraldehyde 3- } \\
\text { phosphate dehydrogenase }\end{array}$ & 50 & 8.0 & 40.0 & - & 1 & - & 0.7 & 2 & 7.1 & - \\
\hline S. thermophilus & Q03LI0 & Enolase & 2643 & 64.1 & 50.6 & 0.1 & 70 & 1.1 & 0.3 & 77 & NN & $9.1 \uparrow$ \\
\hline S. thermophilus & Q5M2M7 & $\begin{array}{l}\text { Glyceraldehyde-3-phosphate } \\
\text { dehydrogenase }\end{array}$ & 1364 & 35.2 & 39.2 & 0.4 & 41 & 1.1 & 0.7 & 43 & NN & $2.8 \uparrow$ \\
\hline S. thermophilus & Q5M1M9 & 60 kDa chaperonin & 637 & 30.4 & 61.9 & 0.2 & 23 & NN & 0.3 & 26 & NN & $6.7 \uparrow$ \\
\hline S. thermophilus & P23989 & $\beta$-galactosidase & 112 & 5.0 & 127.0 & 0.2 & 4 & 1.5 & 0.4 & 6 & 1.4 & $4.5 \uparrow$ \\
\hline S. thermophilus & Q5M5N6 & $\begin{array}{l}\text { NADP-specific glutamate } \\
\text { dehydrogenase[gdhA] }\end{array}$ & 44 & 4.2 & 52.8 & 0.2 & 3 & 1.4 & 0.4 & 3 & 1.1 & $5.0 \uparrow$ \\
\hline Bos taurus & Q2UVX4 & Complement C3 & 2334 & 26.4 & 206.5 & 0.7 & 99 & NN & 0.7 & 97 & NN & $1.5 \uparrow$ \\
\hline Bos taurus & Q95114 & Lactadherin & 1966 & 50.6 & 51.0 & 1.4 & 85 & 1.1 & 1.3 & 84 & NN & $1.4 \downarrow$ \\
\hline Bos taurus & P24627 & Lactotransferrin (lactoferrin) & 1603 & 32.5 & 88.1 & 0.4 & 64 & NN & 0.4 & 64 & NN & $2.3 \uparrow$ \\
\hline Bos taurus & P81265 & $\begin{array}{l}\text { Polymeric-immunoglobulin } \\
\text { receptor }\end{array}$ & 1056 & 17.7 & 90.8 & 1.6 & 41 & 1.1 & 1.3 & 42 & 1.1 & $1.6 \downarrow$ \\
\hline Bos taurus & P80195 & Lactophorin & 878 & 39.9 & 19.2 & 2.1 & 51 & 1.8 & 1.5 & 50 & 1.5 & $2.1 \downarrow$ \\
\hline Bos taurus & P80457 & $\begin{array}{l}\text { Xanthine dehydrogenase/ } \\
\text { oxidase }\end{array}$ & 878 & 18.8 & 161.8 & 0.7 & 51 & NN & 0.7 & 53 & NN & $1.4 \uparrow$ \\
\hline Bos taurus & P26201 & Platelet glycoprotein 4 & 498 & 9.3 & 58.5 & 1.4 & 13 & 1.3 & 1.0 & 13 & 1.2 & $1.4 \downarrow$ \\
\hline Bos taurus & A4IFI0 & MGC151892 & 491 & 14.5 & 27.0 & 1.3 & 12 & 1.1 & 1.2 & 13 & 1.1 & $1.3 \downarrow$ \\
\hline Bos taurus & P02754 & $\beta$-lactoglobulin & 254 & 26.4 & 22.7 & 1.7 & 7 & 1.3 & 1.1 & 7 & 1.3 & $1.7 \downarrow$ \\
\hline Bos taurus & A5D7Q2 & $\begin{array}{l}\text { Putative uncharacterized } \\
\text { protein }\end{array}$ & 232 & 5.1 & 56.0 & 1.6 & 8 & 1.1 & 1.3 & 8 & 1.1 & $1.6 \downarrow$ \\
\hline Bos taurus & P02769 & Serum albumin & 196 & 8.4 & 80.0 & 1.5 & 8 & NN & 0.9 & 7 & 1.3 & $1.5 \downarrow$ \\
\hline Bos taurus & P80025 & Lactoperoxidase & 182 & 11.1 & 87.4 & 1.0 & 11 & 1.1 & 0.9 & 12 & 1.2 & 1.0 \\
\hline Bos taurus & P02666 & $\beta$-casein & 103 & 10.3 & 27.0 & 6.1 & 4 & 1.6 & 8.5 & 4 & 1.6 & $6.1 \downarrow$ \\
\hline Bos taurus & Q27960 & $\begin{array}{l}\text { Na-dependent phosphate } \\
\text { transport protein } 2 \mathrm{~B}\end{array}$ & 99 & 4.6 & 83.3 & 1.6 & 4 & 1.3 & 0.9 & 3 & 1.7 & $1.6 \downarrow$ \\
\hline Bos taurus & P10790 & $\begin{array}{l}\text { Fatty acid-binding protein. } \\
\text { heart }\end{array}$ & 85 & 14.3 & 16.8 & 1.4 & 3 & 1.3 & 1.2 & 3 & 1.5 & $1.4 \downarrow$ \\
\hline Bos taurus & Q29443 & Serotransferrin & 83 & 4.5 & 89.2 & 0.5 & 4 & NN & 0.5 & 4 & NN & $2.0 \uparrow$ \\
\hline Bos taurus & P02662 & $\alpha_{\mathrm{S} 1}$-casein & 72 & 8.4 & 26.9 & 1.0 & 4 & 1.4 & 1.0 & 4 & 1.5 & 1.0 \\
\hline Bos taurus & P18892 & $\begin{array}{l}\text { Butyrophilin subfamily } 1 \\
\text { member A1 }\end{array}$ & 67 & 6.8 & 63.6 & 1.8 & 5 & 1.5 & 1.5 & 5 & 1.6 & $1.8 \downarrow$ \\
\hline Bos taurus & Q4GZT4 & $\begin{array}{l}\text { ATP-binding cassette sub- } \\
\text { family G member } 2\end{array}$ & 33 & 3.4 & 79.4 & 1.9 & 2 & 1.9 & 0.8 & 2 & 1.1 & $1.9 \downarrow$ \\
\hline
\end{tabular}

Values in this table represent the average values of 3 successive injections analysed in ESI and MALDI as given by MASCOT via merging of the 6 data files.

a Accession number of the protein in the SwissProt/Uniprot database.

b Protein score is the sum of the highest ions score for each distinct sequence.

c Percent coverage determines the percent of the residues in each protein sequence that have been identified.

d Value of molecular mass of the protein from the SwissProt/Uniprot database.

e $\mathrm{N}$ represents the number of iTRAQ peptide ratios that contributed in the calculation of the protein average ratio.

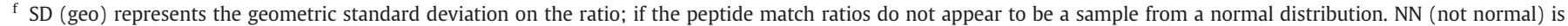
displayed.

throughout the ripening time. In these Swiss-type cheeses, intracellular proteins from the ripening flora, $P$ freudenreichii, were not found because they grow during ripening and they only slightly lysed at the end of the ripening time (Valence et al., 1998). We observed a higher number of proteins identified from $L$ helveticus than from $S$. thermophilus, suggesting a higher release of the lactobacilli proteins in the cheese matrix subsequently to cell death and lysis. From the numeration plate, we showed that $L$ helveticus was enumerated at the end of ripening at up to $910^{4}$ and $3.310^{6} \mathrm{cfu} / \mathrm{g}$ for cheeses $\mathrm{A}$ and B respectively, while $S$ thermophilus was not enumerated on plate anymore. This discrepancy between numeration and proteins released into the cheese matrix led to the question of the cells which are really dead and lysed and cells that can be still metabolically active and not able to be cultivated again on plate; this point was recently clarified by Falentin et al. (2012), as these authors showed that most of the thermophilic starters cells (80-90\%) remained metabolically active during the whole ripening. In this case, proteins remained into the cells and are not released into the cheese matrix to be identified and quantified which can thus contribute to explain why so few bacterial proteins are detected in the aqueous extract 

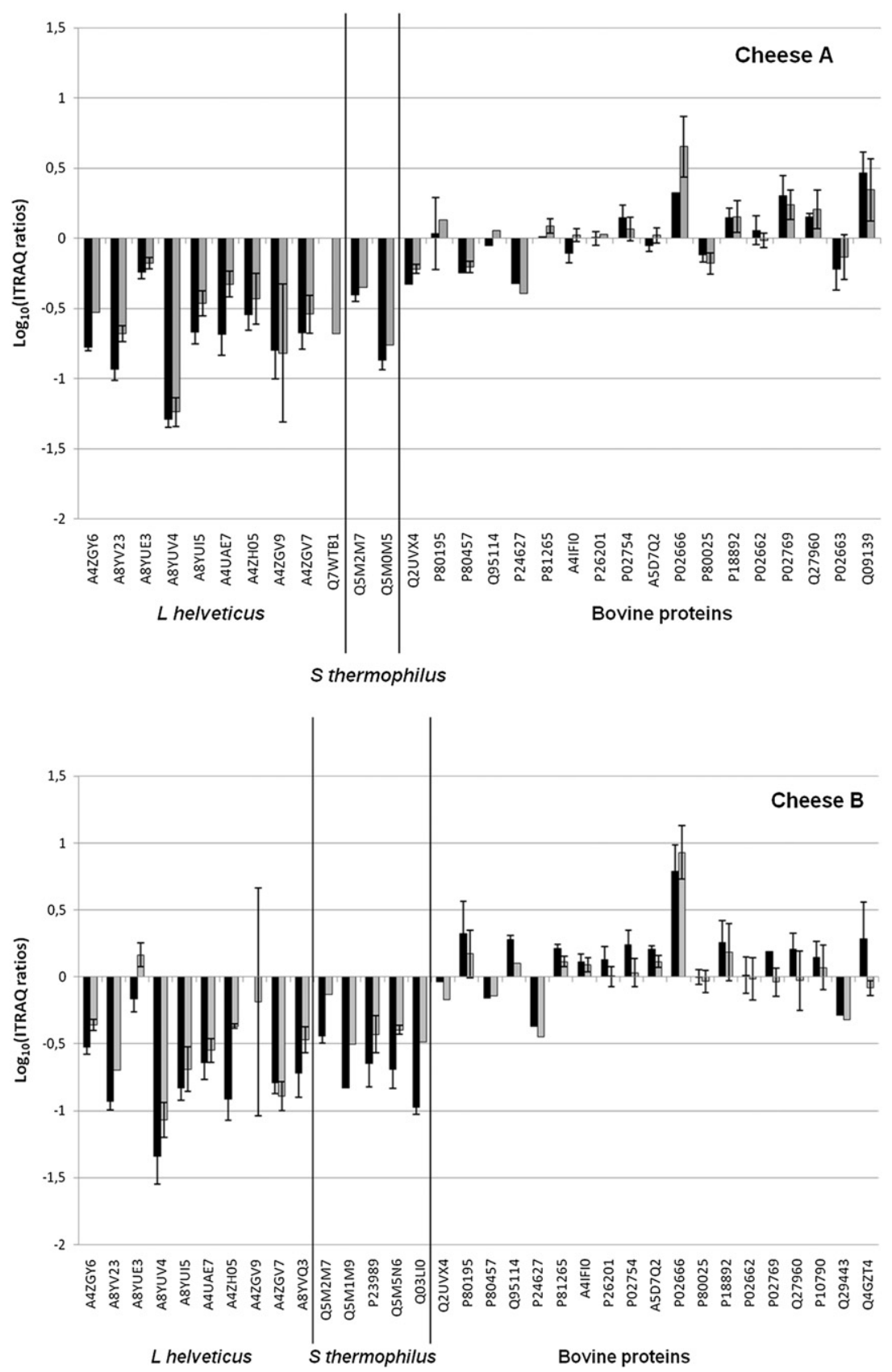

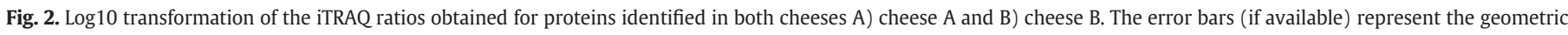

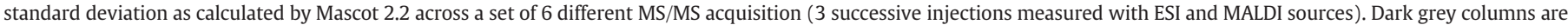
$\log 10$ transformation of iTRAQ ratios (Day 7/Day 69); light grey columns are log10 transformations of iTRAQ ratios (D 20/Day 69).

compared to the hundreds expressed. In the present study, care must be taken when interpreting the quantities measured as the increase in the concentration of proteins can be due not only to a higher number of cells that can lyse but also to a greater expression of protein inside the cell, which in turn can release a higher level of proteins into the cheese when lysis occurs. Which one of these two mechanisms is responsible for the variation in ITRAQ ratios measured cannot be elucidated with the present experimental setup.

However, we confirmed that the lactic starter encountered stress during Emmental manufacture (Gagnaire et al., 2004), and, in turn, generated a severe stress response as shown by the high number of peptides identified from the 60kda chaperonin of $L$ helveticus (A4ZGY6) and S thermophilus (Q5M1M9) reflecting high abundance of these proteins in our sample early during the ripening process. A bacterial stress response was also observed recently for L. lactis in cheese by microarray analysis (Cretenet et al., 2011).

The other bacterial proteins identified are mainly glycolytic enzymes (pyruvate kinase A8YV23, enolase A8YUV4, glucose-6phosphate isomerase A8YUI5, L-lactate dehydrogenase A4UAE7, phosphoglycerate kinase A8YUE3, fructose-1.6-biphosphate aldolase A4ZGV7, glyceraldehyde 3-phosphate dehydrogenase A4ZGV9 and Q5M2M7, ß-galactosidase P23989, NADP-specific glutamate dehydrogenase Q5M5N6). All these proteins showed an increase in their concentration in the aqueous phase throughout ripening. Their release was greater between D20 and D69 of ripening than between D7 and D20. The amount of bacterial proteins varied differently during ripening, with a range of fold change from 2 to 20 . This variation further demonstrates the quantification not only of bacterial cell lysis 
but also of the difference in protein expression. In situ transcriptomic expression of L. lactis in cheese at different step of the ripening highlighted the overexpression of most of the glycolytic pathway genes, which is coherent with the type of enzymes identified here (Cretenet et al., 2011). Moreover, a higher release was observed during the ripening at $24{ }^{\circ} \mathrm{C}$ for 3 weeks (between D20 and D69). Only three bacterial proteins were shown to be released more between D7 and D20: inosine-5'-monophosphate dehydrogenase, and Llactate dehydrogenase from $L$ helveticus in cheese B and A respectively and enolase from $S$ thermophilus in cheese B.

Some intracellular proteins, besides their main function in glycolysis, can display secondary activities in cell adhesion and have been shown to be present at the cell surface by a mechanism which is not well elucidated yet. This is the case for enolase (A8YUV4 and Q5MOM5) and glyceraldehyde-3-phosphate dehydrogenase (A4ZGV9 and Q5M2M7), which are also produced at high level in cells compared to other intracellular proteins (Izquierdo et al., 2009; Pancholi, 2001). Enolase had actually the highest relative increase during ripening for both species of LAB. Indeed, we observed a global fold change of 7.7 and 9.1 for $S$ thermophilus and of 20 for L helveticus between D7 and D69. Glyceraldehyde-3-phosphate dehydrogenase from $L$ helveticus, was in contrast differently released according to the cheeses. The fold change between D7 and D29 was 6.3 in cheese $\mathrm{A}$ and 1.4 in cheese B while the enzyme from $S$ thermophilus had a similar fold change 2.6-2.8 in both cheeses. Both enolase and glyceraldehyde-3-phosphate dehydrogenase were shown to be over expressed as well as pyruvate kinase during propagation in cheese whey and exposure to temperature gradient naturally decreasing (55 to $20^{\circ} \mathrm{C}$ ) (Di Cagno et al., 2006).

\section{Concluding remarks}

In this study, predominant bacterial and bovine proteins were successfully quantified during ripening using the ITRAQ labelling technique that was first applied to complex dairy matrices. However, improvement could be made to increase the level of identification and quantification of the bacterial proteins by using 2D chromatographic separation prior to coupling with tandem mass spectrometry. This will permit to decrease the peptide co-elution and therefore maximize the number of peptides identified and quantified. In order to better assess bacterial metabolism at different times of ripening, this approach could be applied to proteins contained within a pellet of entire bacterial cells harvested from the cheese matrix versus the free proteins present at the same time in the cheese aqueous extracts. No doubt that, even challenging, in situ bacterial protein quantification is crucial to really understand the relationship between bacterial starter metabolism and cheese composition or technology.

Supplementary materials related to this article can be found online at doi:10.1016/j.ijfoodmicro.2012.01.008.

\section{Acknowledgment}

The authors are indebted to Bénédicte Camier for her support in the manufacture of Swiss-type cheeses, and to Stéphane Pezennec for fruitful help with the statistical analysis of the quantification results.

\section{References}

Bachmann, H.P., Bütikofer, U., Badertscher, R., Dallatorre, M., Lavanchy, P., Buhler-Moor, U. Nick, B., Jimeno, J., Warmke, R., Grosch, W., Sieber, R., Bosset, J.O., 1997. Ripening of Emmental cheese wrapped in foil with and without addition of Lactobacillus case subsp. casei. I. Microbial, chemical, rheological and sensoral investigations (in deutsch). Lebensmittel-Wissenschaft und Technologie 30, 417-428.

Beuvier, E., Berthaud, K., Cegarra, S., Dasen, A., Pochet, S., Buchin, S., Duboz, G., 1997 Ripening and quality of Swiss-type cheese made from raw, pasteurized or microfiltered milk. International Dairy Journal 7, 311-323.
Choe, L., D'Ascenzo, M., Relkin, N.R., Pappin, D., Ross, P., Williamson, B., Guertin, S., Pribil, P., Lee, K.H., 2007. 8-Plex quantitation of changes in cerebrospinal fluid protein expression in subjects undergoing intravenous immunoglobulin treatment for Alzheimer's disease. Proteomics 7, 3651-3660.

Chong, P.K., Gan, C.S., Pham, T.K., Wright, P.C., 2006. Isobaric tags for relative and absolute quantitation (iTRAQ) reproducibility: implication of multiple injections. Journal of Proteome Research 5, 1232-1240.

Cong, Y.S., Fan, E., Wang, E., 2006. Simultaneous proteomic profiling of four different growth states of human fibroblasts, using amine-reactive isobaric tagging reagents and tandem mass spectrometry. Mechanisms of Ageing and Development 127, 332-343.

Cretenet, M., Laroute, V., Ulve, V., Jeanson, S., Nouaille, S., Even, S., Piot, M., Girbal, L., le Loir, Y., Loubiere, P., Lortal, S., Cocaign-Bousquet, M., 2011. Dynamic analysis of the Lactococcus lactis transcriptome in cheeses made from milk concentrated by ultrafiltration reveals multiple strategies of adaptation to stresses. Applied and Environmental Microbiology 77, 247-257.

Danielsen, M., Hornshoj, H., Siggers, R.H., Jensen, B.B., vanKessel, A.G., Bendixen, E., 2007. Effects of bacterial colonization on the porcine intestinal proteome. Journal of Proteome Research 6, 2596-2604.

Delahunty, C., Yates, J.R., 2005. Protein identification using 2D-LC-MS/MS. Methods 35, 248-255.

Di Cagno, R., De Angelis, M., Limitone, A., Fox, P.F., Gobbetti, M., 2006. Response of Lactobacillus helveticus PR4 to heat stress during propagation in cheese whey with a gradient of decreasing temperatures. Applied and Environmental Microbiology $72,4503-4514$

Falentin, H., Henaff, N., Le Bivic, P., Deutsch, S.M., Parayre, S., Richoux, R., Sohier, D., Thierry, A., Lortal, S., Postollec, F., 2012. Reverse transcription quantitative PCR revealed persistency of thermophilic lactic acid bacteria metabolic activity until the end of the ripening of Emmental cheese. Food Microbiology 29, $132-140$.

Fenselau, C., 2007. A review of quantitative methods for proteomic studies. Journal of Chromatography. B, Analytical Technologies in the Biomedical and Life Sciences 855, 14-20.

Gagnaire, V., Piot, M., Camier, B., Vissers, J.P.C., Jan, G., Léonil, J., 2004. Survey of bacterial proteins released in cheese: a proteomic approach. International Journal of Food Microbiology 94, 185-201.

Gagnaire, V., Jardin, J., Jan, G., Lortal, S., 2009. Invited review: proteomics of milk and bacteria used in fermented dairy products: from qualitative to quantitative advances. Journal of Dairy Science 92, 811-825.

Gygi, S.P., Rist, B., Gerber, S.A., Turecek, F., Gelb, M.H., Aebersold, R., 1999. Quantitative analysis of complex protein mixtures using isotope-coded affinity tags. Nature Biotechnology 17, 994-999.

Hugli, T.E., Moore, S., 1972. Determination of the tryptophan content of proteins by ion exchange chromatography of alkaline hydrolysates. Journal of Biological Chemistry 247, 2828-2834.

Izquierdo, E., Horvatovich, P., Marchioni, E., oude-Werner, D., Sanz, Y., Ennahar, S., 2009. 2-DE and MS analysis of key proteins in the adhesion of Lactobacillus plantarum, a first step toward early selection of probiotics based on bacterial biomarkers. Electrophoresis 30, 949-956.

Jagtap, P., Michailidis, G., Zielke, R., Walker, A.K, Patel, N. Strahler, J.R., Driks, A. Andrews, P.C., Maddock, J.R., 2006. Early events of Bacillus anthracis germination identified by time-course quantitative proteomics. Proteomics 6, 5199-5211.

Kim, J.S., Kim, J.Y., Kim, H.J., 2005. Suppression of matrix clusters and enhancement of peptide signals in MALDI-TOF mass spectrometry using nitrilotriacetic acid. Analytical Chemistry 77, 7483-7488.

Kuchroo, C.N., Fox, P.F., 1982. Soluble nitrogen in Cheddar cheese: comparison of extraction procedures. Milchwissenschaft 37, 331-335.

Kussendrager, K.D., van Hooydonk, A.C.M., 2000. Lactoperoxidase: physico-chemical properties, occurrence, mechanism of action and applications. The British Journal of Nutrition 84, S19-S25.

Lippolis, J.D., Peterson-Burch, B.D., Reinhardt, T.A., 2006. Differential expression analysis of proteins from neutrophils in the periparturient period and neutrophils from dexamethasone-treated dairy cows. Veterinary Immunology and Immunopathology $111,149-164$.

Lund, T.C., Anderson, L.B., McCullar, V., Higgins, L., Yun, G.H., Grzywacz, B., Verneris, M.R., Miller, J.S., 2007. iTRAQ is a useful method to screen for membrane-bound proteins differentially expressed in human natural killer cell types. Journal of Proteome Research 6, 644-653.

Moore, S., 1963. On the determination of cystine as cysteic acid. Journal of Biological Chemistry 238, 235-237.

O'Donnell, R., Holland, J.W., Deeth, H.C., Alewood, P., 2004. Milk proteomics. International Dairy Journal 14, 1013-1023.

Pancholi, V., 2001. Multifunctional alpha-enolase: its role in diseases. Cellular and Molecular Life Sciences 58, 902-920.

Reinhardt, T.A., Lippolis, D., 2006. Bovine milk fat globule membrane proteome. The Journal of Dairy Research 73, 406-416.

Reinhardt, T.A., Lippolis, J.D., 2008. Developmental changes in the milk fat globule membrane proteome during the transition from colostrum to milk. Journal of Dairy Science 91, 2307-2318.

Ross, P.L., Huang, Y.N., Marchese, J.N., Williamson, B., Parker, K., Hattan, S., Khainovski, N., Pillai, S., Dey, S., Daniels, S., Purkayastha, S., Juhasz, P., Martin, S., Bartlet-Jones, M., He, F., Jacobson, A., Pappin, D.J., 2004. Multiplexed protein quantitation in Saccharomyces cerevisiae using amine-reactive isobaric tagging reagents. Molecular \& Cellular Proteomics 3, 1154-1169.

Sachon, E., Mohammed, S., Bache, N., Jensen, O.N., 2006. Phosphopeptide quantitation using amine-reactive isobaric tagging reagents and tandem mass spectrometry: 
application to proteins isolated by gel electrophoresis. Rapid Communications in Mass Spectrometry 20, 1127-1134.

Scherl, A., Francois, P., Charbonnier, Y., Deshusses, J., Koessler, T., Huyghe, A., Bento, M., Stahl-Zeng, J., Fischer, A., Masselot, A., Vaezzadeh, A., Galle, F., Renzoni, A., Vaudaux, P., Lew, D., Zimmermann-Ivol, C., Binz, P.A., Sanchez, J.C., Hochstrasser, D., Schrenzel, J., 2006. Exploring glycopeptide-resistance in Staphylococcus aureus: a combined proteomics and transcriptomics approach for the identification of resistance-related markers. BMC Genomics 7, 296.

Sheehan, A., O'Loughlin, C., O'Cuinn, G., Fitzgerald, R.J., Wilkinson, M.G., 2005. Cheddar cheese cooking temperature induces differential lactococcal cell permeabilization and autolytic responses as detected by flow cytometry: implications for intracellular enzyme accessibility. Journal of Applied Microbiology 99, 1007-1018.

Spackman, D.H., Stein, W.H., Moore, S., 1958. Automatic recording apparatus for use in chromatography of amino acids. Analytical Chemistry 30, 1190-1206.

Sui, J., Tan, T.L., Zhang, J., Ching, C.B., Chen, W.N., 2007. iTRAQ-coupled 2D LC-MS/MS analysis on protein profile in vascular smooth muscle cells incubated with $\mathrm{S}$ - and R- enantiomers of propranolol: possible role of metabolic enzymes involved in cellular anabolism and antioxidant activity. Journal of Proteome Research 6, 1643-1651.

Thierry, A., Salvat-Brunaud, D., Madec, M.N., Michel, F., Maubois, J.L., 1998. Affinage de l'emmental: dynamique des populations bactériennes et évolution de la composition de la phase aqueuse. Le Lait 78, 521-542.

Trouvé, E., Maubois, J.L., Piot, M., Madec, M.N., Fauquant, J., Rouault, A., Tabard, J., Brinkman, G., 1991. Rétention de différentes espèces microbiennes lors de l'épuration du lait par microfiltration en flux tangentiel. Le Lait 71, 1-13.

Valence, F., Richoux, R., Thierry, A., Palva, A., Lortal, S., 1998. Autolysis of Lactobacillus helveticus and Propionibacterium freudenreichii in Swiss cheeses: first evidence by using species-specific lysis markers. The Journal of Dairy Research 65, 609-620.

Wiese, S., Reidegeld, K.A., Meyer, H.E., Warscheid, B., 2007. Protein labeling by iTRAQ: a new tool for quantitative mass spectrometry in proteome research. Proteomics 7 , 340-350. 